\title{
The effect of Verotoxin Producing Escherichia coli in Development of Experimental Gastroenteritis among Streptomycin Treated Murine Model: A Longitudinal Study
}

\author{
Fahareen-Binta-Mosharraf, Chowdhury Rafiqul Ahsan, Jamalun Nessa, and Mahmuda Yasmin \\ Department of Microbiology, University of Dhaka, Dhaka 1000, Bangladesh
}

\begin{abstract}
Escherichia coli 0157:H7 is a newly emerged pathogen, which has been recognized as a major cause of large scale epidemics and thousands of sporadic cases of gastrointestinal illness. This observation particularly calls for the in vivo examination of $E$. coli $\mathrm{O} 157$ candidates in an attempt to mimic various aspects of $E$. coli 0157:H7 disease symptoms in humans. Healthy conventional Swiss albino mice were used for investigating the clinical manifestation exerted by stx1A and stx2A positive $E$. coli $0157: H 7$ in various doses applied through three alternative routes (oral, intramuscular and intraperitoneal). The highest titer of orally added $E$. coli

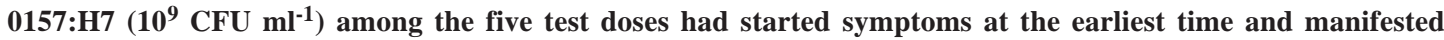
most of the classical symptoms. The symptoms started to become visible at $14^{\text {th }}$ hour, increased with time and had reached moribund condition near $48^{\text {th }}$ hour just before death of the host. The oral way of $E$. coli $0157: H 7$ addition at the dose of $100 \mu \mathrm{l}$ suspension containing $1 \times 10^{9} \mathrm{CFU} \mathrm{ml}{ }^{-1}$ was taken as the most potent concentration in producing bacterial fatality and hence was selected as the Minimum Lethal Dose (MLD).
\end{abstract}

Key words: E. coli 0157:H7 infection, streptomycin treated murine model

\section{Introduction}

Enterohemorrhagic Escherichia coli (EHEC) is an important group of multiple food and water-borne pathogens. EHEC, including $E$. coli O157:H7 comprises a subset of Shiga toxin-producing E. coli (STEC). E.coli O157:H7 has become a worldwide threat to public health and is one of today's most troubling food-borne pathogens. It has been known to be a human pathogen for nearly 30 years $^{1-2}$.

E.coli O157:H7 is a newly emerged pathogen, which has been the focus of immense international research effort driven by its recognition as a major cause of large-scale epidemics and thousands of sporadic cases of gastrointestinal illness. At least 30 countries in six continents have reported E. coli O157:H7 infections in humans ${ }^{3}$. E. coli O157:H7 infection can manifest in a variety of ways. Some individuals who are infected with the microbe remain asymptomatic, others experience diarrhea, but most develop hemorrhagic colitis (HC), the hallmark of $E$. coli O157:H7 infection. Children and the elderly appear to be especially susceptible to E. coli O157:H7 mediated disease and for reasons that are unclear, may develop HUS (a triad of clinical manifestations including hemolytic anemia, thrombocytopenia, and renal failure ${ }^{3}$ and other systemic problems that include central nervous system impairment ${ }^{4}$.

The incubation period for disease caused by EHEC O157:H7 among human population ranges from 1 to 16 days. Most infections become apparent after 3-4 days; however, the median incubation period was eight days ${ }^{5}$ in one outbreak at an institution (Figure 1).

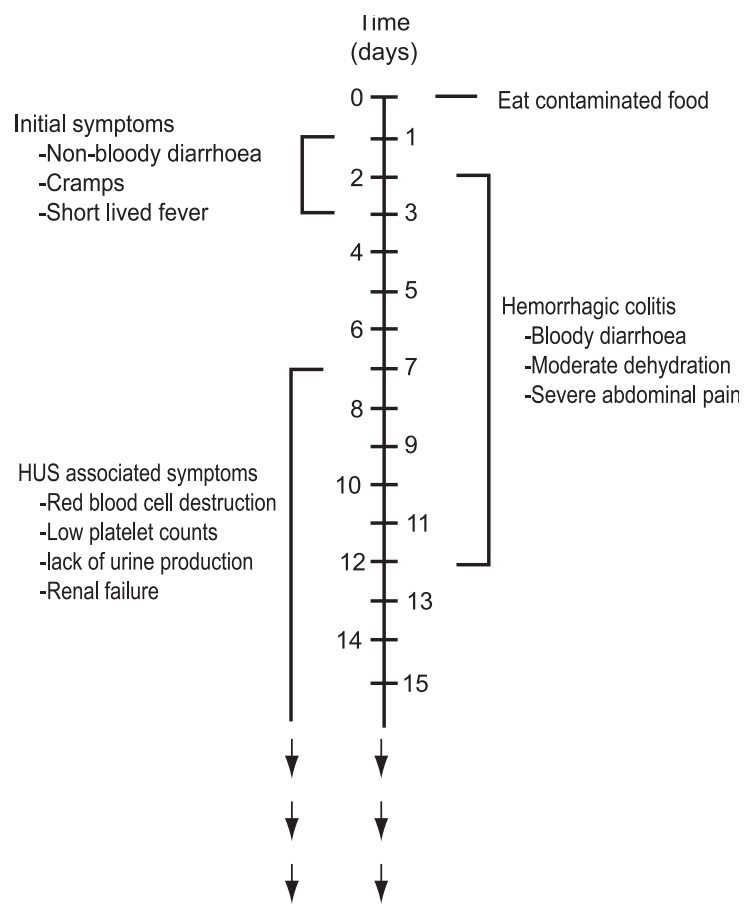

Figure 1. Symptoms and time course of E. coli O157:H7 infection 
The centre for disease control (CDC) has estimated that $85 \%$ of E. coli O157:H7 infections are food borne in origin. In fact, consumption of any food or beverage that becomes contaminated by animal (especially cattle) manure can result in contracting the disease. Foods that have been sources of contamination include ground beef, venison, sausages, dried (non-cooked) salami, unpasteurized milk and cheese, unpasteurized apple juice and cider $^{6-8}$. The CDC has recently reported E. coli O157:H7 as the fourth most prevalent bacterial diarrheal pathogen after Campylobacter sp., Salmonella sp., and Shigella sp ${ }^{9-10}$.

The pathogenicity of E. coli 0157:H7 is associated with several virulence factors including shiga toxins or verotoxins 1 and 2 encoded by stx $1 A$ and stx $2 A$ genes respectively. The ability to adhere to the intestinal mucosa by intimin (encoded by the eaeA gene) ${ }^{11-12}$ and the production of haemolysin (encoded by the hlyA gene) which lyses erythrocytes release heme and globin that enhance the growth of E. coli 0157:H7 and serve as a source of iron ${ }^{13}$. This potent cytotoxin is the major factor that might lead to many symptoms or even to death in patients infected with EHEC $^{14}$.

A stool or blood culture can detect E. coli O157:H7 when cultured on Sorbitol-MacConkey (SMAC) agar, or the variant SorbitolMacConkey agar containing cefixime and potassium tellurite (CTSMAC $)^{15}$. Non-sorbitol fermenting colonies are tested for the somatic $\mathrm{O} 157$ antigen before being confirmed as E. coli O157. E. coli O157:H7 lacks the ability to hydrolyze 4-methylumbelliferyl$\beta$-D-glucuronide (MUG) and does not grow at $45^{\circ} \mathrm{C}$ in the presence of $0.15 \%$ bile salts ${ }^{16}$.

There are no currently available vaccines to prevent diseases due to EHEC, but a number of experimental approaches are being investigated in animals ${ }^{17-18}$. Numerous in vitro assays and animal models have been developed in an effort to imitate various aspects of E. coli O157:H7 mediated disease production in humans. These models exist in two varieties: those solely focused on the effects of Stx (in the absence of bacteria) and those that explore E. coli O157:H7 infection ${ }^{17}$. Small animals that have served as models for EHEC infection and disease include mice, rats, and rabbits. Larger animals that have been so used, even though less frequently, include chickens, pigs, cows, dogs, baboons, and macaques $^{18}$.

This work examined the clinical manifestation exerted by stx $1 A$ and stx2A positive E. coli O157:H7 in various doses applied through different routes into healthy conventional rodents over a period of time. Furthermore, we tried to find the most potent way of 0157 inoculation in disease production among the three test routes and to determine O157 Minimum Lethal Dose (MLD) in murine population.

\section{Materials and Methods}

E. coli O157:H7 NCTC12079 (clinical strain) was kindly provided by obtained from ICDDR,B (International Center for Diarrheal Disease Research).
Molecular characterization of Escherichia coli O157:H7 DNA by polymerase chain reaction

Bacterial chomosomal DNA was extracted and purified according to GuSCN DNA extraction method ${ }^{19}$.

Polymerase chain reaction based detection of stx $1 \mathrm{~A}$ and stx2A gene from extracted DNA sample was performed by following the method of Brown ${ }^{20}$.

PCR was performed in a thermal cycler (Bio-Rad, Model:C1000 ${ }^{\mathrm{TM}}$ )

Extracted DNA from Escherichia coli O157:H7 NCTC 12079 was used as positive control to detect the presence of stx 1 and st 2 . One hundred base pair DNA (Invitrogen, Cat No: 15628-050) was used as marker to measure the molecular size of the amplified products. DNA bands were detected by staining the gel with aqueous ethidium bromide $(0.5 \mu \mathrm{g} / \mathrm{ml})$ for 20 minutes and destained with ethnol for 30 minutes at room temperature and photographs were taken using gel documentation system (BioRad, USA).

Mice infection protocol with increasing dose of E.coli O157:H7

One hundred and eight Swiss albino mice (Mus musculus) of 6-8 weeks age was purchased from Animal Division of ICDDR,B. Mice were weighed individually on day 0 and a common body weight was recorded as $18 \mathrm{~g}$. Heart beat was noted as 110-120/ minute. Each mouse was examined initially for their state of health including body temperature, appetite condition, and tidiness of fur, eye health and activity level. The mice were randomly selected on the basis of experimental scheme and to verify the reproducibility of the outcome each set of investigation was performed in duplication.

Mice were housed under standard day length, temperature, and humidity conditions. Each cage contained a control mouse devoid of any treatment, maintained with normal mice feed and drinking water. The treated group after specific treatment was given normal mice feed and drinking water.

To demonstrate the infective capacity of E. coli O157:H7 in murine model, three sets of mice (set-1, set-2, and set-3) each containing six animals were administrated with specific dose of $E$. coli O157:H7 culture through three different routes of entry: oral, intramuscular (i.m.) and intraperitoneal (i.p.). Over the course of infection the animals were observed daily for their activity level, water intake and amount of food consumption.

Pellet to be inoculated orally was re-suspended in $1 \mathrm{ml}$ of $1 \%$ sucrose solution. Pellet/bacterial seed to be administered via i.m. and i.p. route was re-suspended in $1 \mathrm{ml}$ PBS solution.

Different sets of mice were inoculated intramuscularly (set 2) intraperitoneally (set 3) following an identical (Table 1) bacterial titer plan. Set 1 mice were given phage free drinking water with streptomycin $(5 \mathrm{~g} / \mathrm{L})$ for one day to reduce the count of normal facultative resident flora of the intestine. All of the three groups of mice (set-1, set-2 and set-3) were starved for $24 \mathrm{hrs}$. 
Table 1. Various titers of orally administered E. coli O157:H7

\begin{tabular}{cccc}
\hline Animal model & $\begin{array}{c}\text { Mouse } \\
\text { identification } \\
\text { number (ID No) } \\
\text { in each set }\end{array}$ & Dose $\left(\mathrm{CFU} \mathrm{ml}{ }^{-1}\right)$ scheme \\
\hline A1/B1 & Dose 1 & $\begin{array}{c}\text { Negative control } \\
(1 \% \text { aqueous } \\
\text { Mice set-1 }\end{array}$ \\
& A2/B2 & Dose 2 & $1 \mathrm{X} 10^{5}$ \\
& A3/B3 & Dose 3 & $1 \mathrm{X} 10^{6}$ \\
& A4/B4 & Dose 4 & $1 \times 10^{7}$ \\
& A5/B5 & Dose 5 & $1 \times 10^{8}$ \\
A6/B6 & Dose 6 & $1 \times 10^{9}$ \\
\hline
\end{tabular}

Mice of the first set were fed with $100 \mu \mathrm{l}$ of $3 \%$ sodium bicarbonate by calibrated dropper to neutralize the stomach acidic condition. All the oral doses were administrated while the mice were held in a supine position with the head up, allowing the animals to suck the fluid from the tip of micropipette as shown in Figure 2.

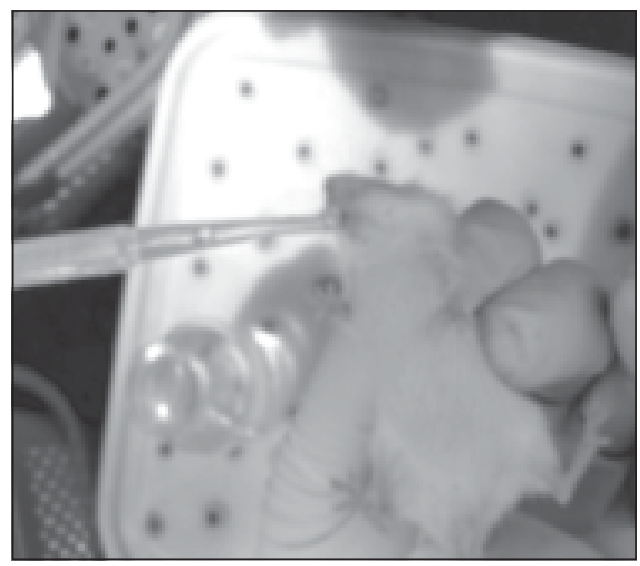

Figure 2. Mouse oral administration pattern

Mice of set- 2 and 3 aimed for i.m. and i.p. treatment following the same dose plan of Table 1 were injected once with $100 \mu \mathrm{l}$ of PBS suspended E. coli 0157:H7 (Figure 3 and 4).

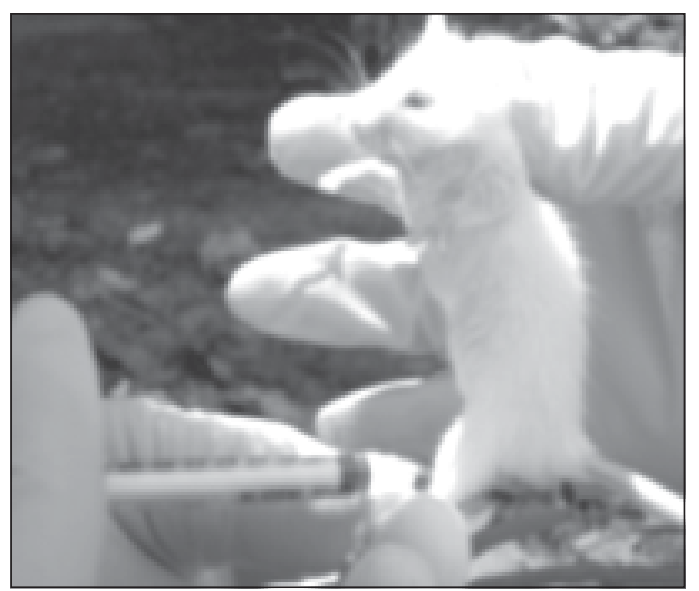

Figure 3. Procedure of mouse intramuscular administration

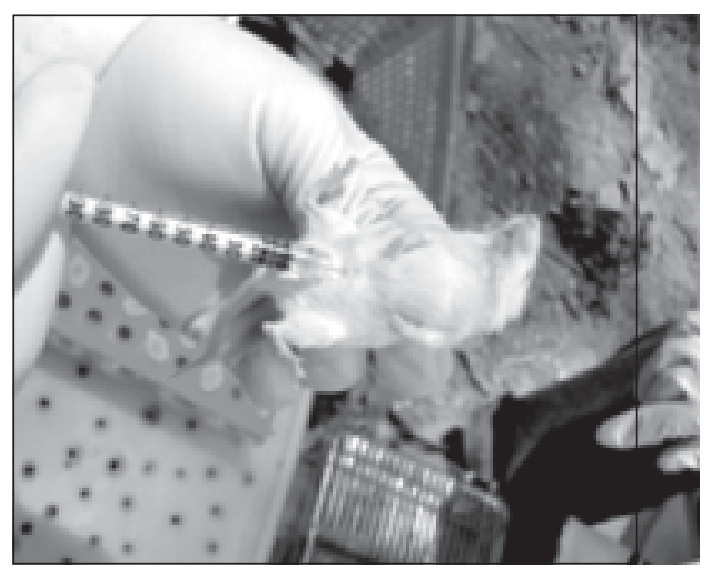

Figure 4. Way of mouse intraperitoneal administration

Determination of disease severity pattern with the increasing dose of E.coli O157:H7

Treated mice of all the three sets (set 1, 2, 3) challenged with different doses of E. coli 0157:H7 (Table 1) along with the untreated (negative control) ones were kept under careful observation for a further 144 hrs to detect any visible change.

Health status of mice was recorded according to the grade chart ${ }^{21}$ labeled as 0-5 which is summarized in Table 2.

Table 2. Increasing dose of E. coli O157:H7 enhances disease severity

\begin{tabular}{ll}
\hline Disease symptoms & $\begin{array}{l}\text { Level of disease } \\
\text { severity }\end{array}$ \\
\hline A normal and unremarkable condition & level 0 \\
$\begin{array}{l}\text { Slight illness, defined as } \\
\text { lethargy and ruffled fur }\end{array}$ & Level 1 \\
$\begin{array}{l}\text { Moderate illness, defined as severe lethargy, } \\
\text { ruffled fur, and hunched back }\end{array}$ & Level 2 \\
$\begin{array}{l}\text { Severe illness, with all the signs plus } \\
\text { exudative accumulation around partially } \\
\text { closed eyes increase body temperature } \\
\text { loss of appetite }\end{array}$ & Level 3 \\
$\begin{array}{l}\text { A moribund state } \\
\text { Death }\end{array}$ & \\
\hline
\end{tabular}

Establishment of minimum lethal dose (MLD) of E.coli O157:H7 for murine model

E. coli 0157 suspensions in PBS were prepared for the calculation of its MLD. The health status of the mice along with the increasing dose of E.coli O157:H7 were recorded. The dose responsible for the death or worst situation (moribund or terminally ill) of murine model was determined to establish the MLD.

To verify if the cause of death was truly due to E. coli O157:H7 bacteremia, blood samples were collected from dead mice by cardiac puncture and then directly spread on CT-SMAC plate. 


\section{Results}

A clinical strain of Escherichia coli O157:H7 obtained from ICDDR,B was confirmed by direct culture onto Sorbitol MacConkey Agar plate (SMAC) containing cefixime and potassium tellurite (CT-Supplement) where E. coli 0157:H7 produced colorless colonies (Fig. 6) and other E. coli K12 gave distinguishable pink colonies (Figure 5).

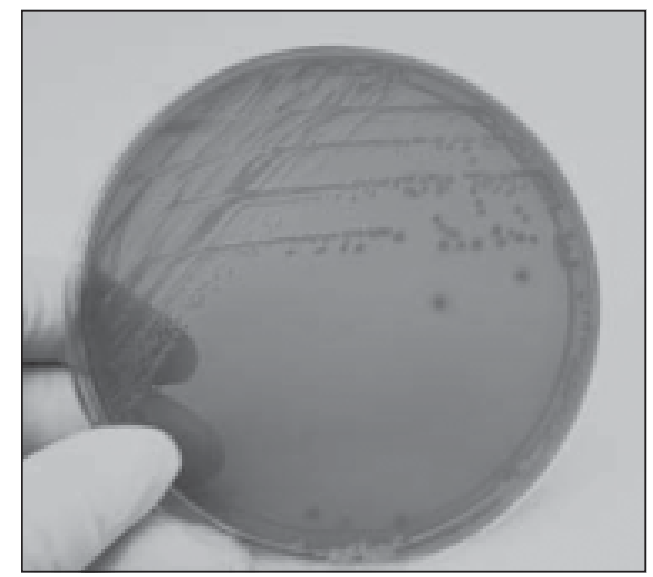

Figure 5. Pink colonies of E. coli O157:H7 along with other E. coli colonies on MacConkey agar

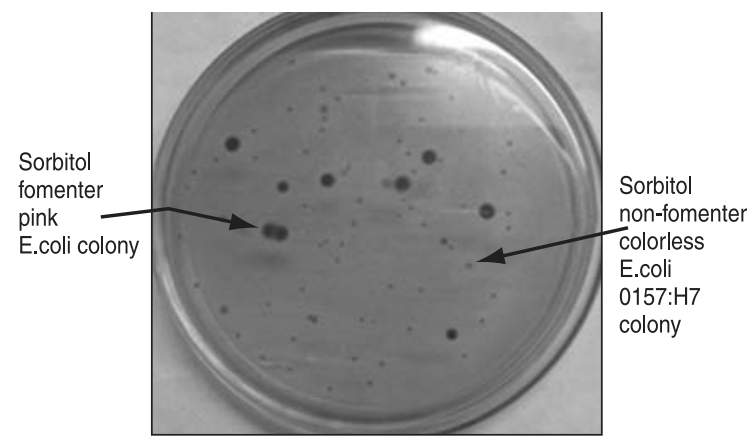

Figure 6. Significant colorless sorbitol non-fermenting E. coli O157:H7 colonies

Colorless colonies from CT-SMAC plate were inoculated in MUG broth where E. coli 0157:H7 showed MUG (4-methylunbelliferyl$\beta$-D-glucuronide) negative (non-fluorescent) growth (E.C. Broth with MUG; Oxoid; England) after exposure to $360 \mathrm{~nm}$ UV light as shown in Figure 7.

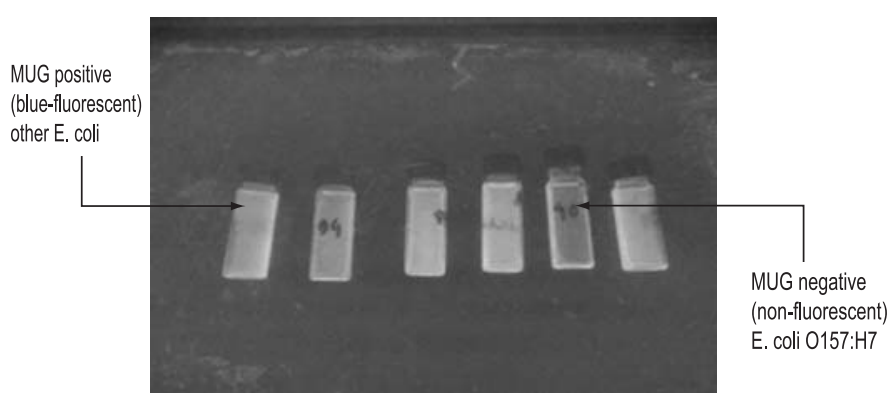

Figure 7. MUG broth showing growth of MUG negative (Nonfluorescent) E. coli O157:H7 isolates and MUG positive (bluefluorescent) other E. coli

\section{Detection of E. coli 0157:H7 specific virulence genes by PCR}

The result revealed that the clinical strain of E. coli O157:H7 used in the research was positive for the presence of $s t x 1 A$ and $s t \times 2 A$ identical to the reference ( Figures 8 and 9).

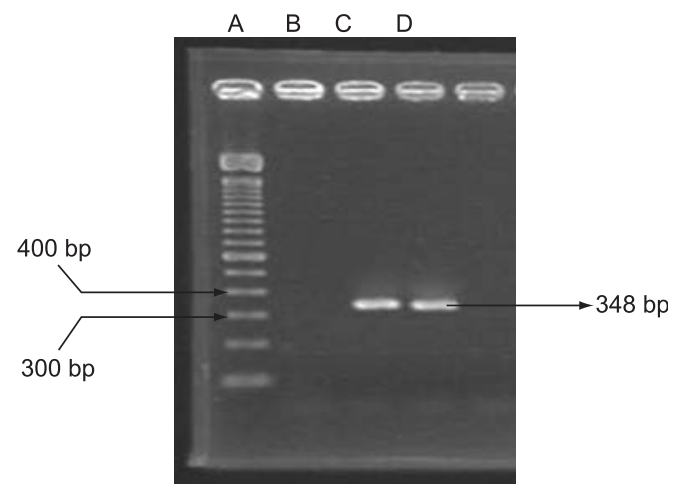

Figure 8. Agarose gel (1\%) electrophoresis pattern of PCR amplicons of E. coli O157:H7 obtained with primers specific for stx 1 A

Key: Lane A-100bp molecular weight marker; Lane B- Negative control E. coli K-12; Lane C- Positive Control E. coli O157:H7 NCTC 12079;Lane D - Test clinical isolates of E.coli O157:H7

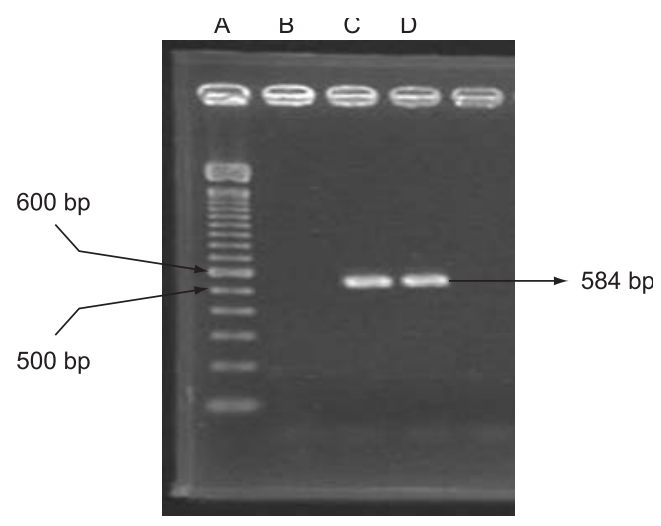

Figure 9. Agarose gel (1\%) electrophoresis pattern of PCR amplicons of E. coli O157:H7 obtained with primers specific for st $x 2 \mathrm{~A}$

Key: Lane A-100bp molecular weight marker; Lane B-Negative control E. coli K-12;

Lane C-Positive Control E. coli O157:H7 NCTC 12079; Lane $D$ - Test clinical isolates of E. coli O157:H7

Effect of Escherichia coli O157:H7 on the outcome of disease severity in murine model

Mice challenged with $10^{5} \mathrm{CFU} \mathrm{ml}{ }^{-1}$ and $10^{6} \mathrm{CFU} \mathrm{ml}^{-1}$ of E. coli 0157:H7 developed no visible symptoms while examined for 144 hrs since infection, whereas doses $3\left(10^{7} \mathrm{CFU} \mathrm{ml}^{-1}\right)$ and dose 4 $\left(10^{8} \mathrm{CFU} \mathrm{ml} \mathrm{l}^{-1}\right)$ produced specific symptoms at specific times but eventually the experimental animals recovered from illness. The highest titer of orally added $E$. coli $\mathrm{O} 157: \mathrm{H7}\left(10^{9} \mathrm{CFU} \mathrm{ml}^{-1}\right)$ caused symptoms at the earliest (at $14^{\text {th }} \mathrm{hr}$ ) time among the five test doses and manifested all the symptoms described in Table 2. 
Moreover, at this particular dose, the inoculated rodent was severely ill at $36^{\text {th }} \mathrm{hr}$ and was dead at $48^{\text {th }}$ hr. The mice fed with $1 \%$ sucrose solution developed none of the above mentioned symptoms and acquired adequate body weight (31.65 g) within this time frame. It could be worthwhile to mention that, all the infected mice (group A2/B2 to A5/B5) did not gain body weight as they should have gained with time and their average weight was measured as $20.15 \mathrm{~g}$ when followed for six days.

Consequence of intramuscularly and intraperitoneally inoculated Escherichia coli O157:H7 on the outcome of disease severity in experimental animal model

To determine the survival pattern of Swiss albino mice of set-2 and 3 (group $\mathrm{An} / \mathrm{Bn}$ ) the mice were injected with increasing dose of $E$. coli O157:H7 according to the list (Table 1) . For both routes $10^{5}$ $\mathrm{CFU} \mathrm{ml}{ }^{-1}$ and $10^{6} \mathrm{CFU} \mathrm{ml}^{-1}$ of E. coli O157:H7 developed no remarkable symptoms when examined for $144 \mathrm{hrs}$ since infection, but in case of dose $4\left(10^{7} \mathrm{CFU} \mathrm{ml}{ }^{-1}\right)$ intramuscularly infected mice gave no visible symptoms whereas intraperitoneally infected mice produced minor symptoms. For dose $5\left(10^{8} \mathrm{CFU} \mathrm{ml}{ }^{-1}\right)$ and dose 6 $\left(10^{9} \mathrm{CFU} \mathrm{ml}{ }^{-1}\right)$ mice produced minor symptoms graded as 1 and 2 (Table 2) at different point of time which was similar for both routes.
Afterwards these infected animals gradually recovered from illness and regained normal health. The mice injected with PBS solution developed none of the above mentioned symptoms and acquired adequate body weight (31.15 g) within this particular period of time.

It could be mentioned that none of the diseased mice (group A2/ B2 to A5/B5) gained body weight as they should have gained with time and their average weight was measured as $22.65 \mathrm{~g}$ at $144^{\text {th }} \mathrm{hr}$.

Determination of minimum lethal dose (MLD) of E.coli O157:H7 To determine the minimum lethal dose (MLD) of E.coli O157:H7 infection in conventional murine model the diseased, moribund and deceased condition of mice were recorded at various time points (Table 3,4 and 5) after bacterial inoculation (in increasing dose) in a six day long experimentation. The disease severity of mice was found to be correlated with the augmented dose of E.coli O157:H7. All the three routes of bacterial inoculation shared this observation. However, the oral route of E.coli O157:H7 addition at a dose of $1 \mathrm{X} 10^{9} \mathrm{CFU} \mathrm{ml}{ }^{-1}$ proved to be the most potent in developing bacterial pathogenesis and hence was selected as the MLD.

Table 3: Disease severity pattern ${ }^{a}$ in mice with increasing dose of orally administered E. coli O157:H7

\begin{tabular}{|c|c|c|c|c|c|c|}
\hline \multirow[b]{2}{*}{$\begin{array}{l}\text { Hours (h) } \\
\text { post } \\
\text { infection }\end{array}$} & \multicolumn{6}{|c|}{ Various doses of E. coli O157:H7 } \\
\hline & $\begin{array}{c}\text { Dose } 1 \\
\text { Negative } \\
\text { Control(1\% } \\
\text { Sucrose } \\
\text { solution ) } \\
\text { Group } \\
\text { A1/B1 }\end{array}$ & $\begin{array}{c}\text { Dose } 2 \\
\left(10^{5} \mathrm{CFU}\right. \\
\left.\mathrm{ml}^{-1}\right) ; \\
\text { Group } \\
\text { A2/B2 }\end{array}$ & $\begin{array}{c}\text { Dose } 3 \\
\left(10^{6} \mathrm{CFU}\right. \\
\left.\mathrm{ml}^{-1}\right) \\
\text { Group } \\
\text { A3/B3 }\end{array}$ & $\begin{array}{c}\text { Dose } 4 \\
\left(10^{7} \mathrm{CFU}\right. \\
\left.\mathrm{ml}^{-1}\right) \\
\text { Group } \\
\text { A4/B4 }\end{array}$ & $\begin{array}{c}\text { Dose } 5 \\
\left(10^{8} \mathrm{CFU}\right. \\
\left.\mathrm{ml}^{-1}\right) \\
\text { Group } \\
\text { A5/B5 }\end{array}$ & $\begin{array}{c}\text { Dose } 6 \\
\left(10^{9} \mathrm{CFU}\right. \\
\left.\mathrm{ml}^{-1}\right) \\
\text { Group } \\
\text { A6/B6 }\end{array}$ \\
\hline 10 & 0 & & & & & 0 \\
\hline 14 & 0 & & & & & 1 \\
\hline 16 & 0 & & & & & 2 \\
\hline 24 & 0 & 0 & 0 & 0 & 0 & 3 \\
\hline 36 & 0 & 0 & 0 & 2 & 2 & 4 \\
\hline 48 & 0 & 0 & 0 & 0 & 1 & 5 \\
\hline 72 & 0 & 0 & 0 & 0 & 0 & \\
\hline 96 & 0 & 0 & 0 & 0 & 0 & \\
\hline 120 & 0 & 0 & 0 & 0 & 0 & \\
\hline 144 & 0 & 0 & 0 & 0 & 0 & \\
\hline
\end{tabular}

${ }^{a}$ Disease severity (0 to 5 ) was recorded according to the grade chart (Table 2) 
Table 4: Illness pattern ${ }^{a}$ in murine model for augmented dose of intramuscularly administered E. coli O157:H7 with time various doses of E. coli O157:H7

\begin{tabular}{|c|c|c|c|c|c|c|}
\hline \multirow[b]{2}{*}{$\begin{array}{l}\text { Hours (h) } \\
\text { post } \\
\text { infection }\end{array}$} & \multicolumn{6}{|c|}{ Various doses of E. coli O157:H7 } \\
\hline & $\begin{array}{c}\text { Dose1 } \\
\text { Negative } \\
\text { Control } \\
\text { (PBS) } \\
\text { Group } \\
\text { A1/B1 } \\
\end{array}$ & $\begin{array}{c}\text { Dose } 2 \\
\left(10^{5} \mathrm{CFU}\right. \\
\left.\mathrm{ml}^{-1}\right) \\
\text { Group } \\
\text { A2/B2 }\end{array}$ & $\begin{array}{c}\text { Dose } 3 \\
\left(10^{6} \mathrm{CFU}\right. \\
\left.\mathrm{ml}^{-1}\right) \\
\text { Group } \\
\text { A3/B3 }\end{array}$ & $\begin{array}{c}\text { Dose } 4 \\
\left(10^{7} \mathrm{CFU}\right. \\
\left.\mathrm{ml}^{-1}\right) \\
\text { Group } \\
\text { A4/B4 }\end{array}$ & $\begin{array}{c}\text { Dose } 5 \\
\left(10^{8} \mathrm{CFU}\right. \\
\left.\mathrm{ml}^{-1}\right) \\
\text { Group } \\
\text { A5/B5 }\end{array}$ & $\begin{array}{c}\text { Dose } 6 \\
\left(10^{9} \mathrm{CFU}\right. \\
\left.\mathrm{ml}^{-1}\right) \\
\text { Group } \\
\text { A6/B6 }\end{array}$ \\
\hline 16 & 0 & 0 & 0 & 0 & 0 & 0 \\
\hline 24 & 0 & 0 & 0 & 0 & 0 & 0 \\
\hline 36 & 0 & 0 & 0 & 0 & 0 & 0 \\
\hline 48 & 0 & 0 & 0 & 0 & 1 & 1 \\
\hline 72 & 0 & 0 & 0 & 0 & 0 & 2 \\
\hline 96 & 0 & 0 & 0 & 0 & 0 & 0 \\
\hline 120 & 0 & 0 & 0 & 0 & 0 & 0 \\
\hline 144 & 0 & 0 & 0 & 0 & 0 & 0 \\
\hline
\end{tabular}

${ }^{a}$ Disease severity (0 to 5 ) was recorded according to the grade chart (Table 2)

Table 5. Survival pattern ${ }^{a}$ of mice with augmented dose of intraperitoneally administered E. coli O157:H7 over time

\begin{tabular}{|c|c|c|c|c|c|c|}
\hline \multirow{9}{*}{$\begin{array}{l}\text { Hours (h) } \\
\text { post } \\
\text { infection }\end{array}$} & \multicolumn{6}{|c|}{ Various doses of E. coli O157:H7 } \\
\hline & Dose1 & Dose 2 & Dose 3 & Dose 4 & Dose 5 & Dose 6 \\
\hline & Negative & & & & & \\
\hline & Control & $\left(10^{5} \mathrm{CFU}\right.$ & $\left(10^{6} \mathrm{CFU}\right.$ & $\left(10^{7} \mathrm{CFU}\right.$ & $\left(10^{8} \mathrm{CFU}\right.$ & $\left(10^{9} \mathrm{CFU}\right.$ \\
\hline & $(1 \%$ & $\left.\mathrm{ml}^{-1}\right)$ & $\left.\mathrm{ml}^{-1}\right)$ & $\left.\mathrm{ml}^{-1}\right)$ & $\left.\mathrm{ml}^{-1}\right)$ & $\left.\mathrm{ml}^{-1}\right)$ \\
\hline & sucrose & Group & Group & Group & Group & Group \\
\hline & solution) & $\mathrm{A} 2 / \mathrm{B} 2$ & A3/B3 & $\mathrm{A} 4 / \mathrm{B} 4$ & A5/B5 & A6/B6 \\
\hline & Group & & & & & \\
\hline & $\mathrm{A} 1 / \mathrm{B} 1$ & & & & & \\
\hline 16 & 0 & 0 & 0 & 0 & 0 & 0 \\
\hline 24 & 0 & 0 & 0 & 0 & 0 & 0 \\
\hline 36 & 0 & 0 & 0 & 0 & 0 & 1 \\
\hline 48 & 0 & 0 & 0 & 1 & 1 & 2 \\
\hline 72 & 0 & 0 & 0 & 0 & 2 & 2 \\
\hline 96 & 0 & 0 & 0 & 0 & 0 & 0 \\
\hline 120 & 0 & 0 & 0 & 0 & 0 & 0 \\
\hline 144 & 0 & 0 & 0 & 0 & 0 & 0 \\
\hline
\end{tabular}

${ }^{a}$ Disease severity (0 to 5) was recorded according to the grade chart (Table 2)

\section{Discussion}

Although it has been nearly 30 years since the discovery of $E$. coli $\mathrm{O} 157: \mathrm{H7}$ as an enteric pathogen and despite the recent rise in the rate of severe diseases associated with infection by this organism, no treatment exists ${ }^{18,22}$. Understanding the pathogenesis of E. coli O157:H7-mediated disease in humans is fairly limited. The use of human subjects to investigate the steps required for E. coli O157:H7 to evoke intestinal pathology is considered unprincipled because of the likelihood that a volunteer could develop HUS. A range of in vitro assays and animal models have been developed in an effort to mimic a range of aspects of E. coli O157:H7 disease production in humans and thus to improvise the potential strategies for prevention and control of E. coli O157:H7 mediated infections in human population.

Large animal models, such as the gnotobiotic piglet, exhibit a number of features of E. coli O157:H7 pathogenesis, but their breeding and maintenance require considerable veterinary skill, space, and ûnancial support ${ }^{17}$. Therefore small animal model systems are preferable for general use. Mouse models in particular offer a number of beneûts that include: low relative costs for 
purchase and maintenance, ease of care and handling, ready availability of numerous immunological reagents, variations in genetic background among inbred mouse strains as well as access to transgenic and recombinant inbred animals, and, very importantly, the feasibility of using sufficient numbers of animals in a single study to perform meaningful statistical analyses on the resultant data. Several popular mouse models of $E$. coli O157:H7 infection have been used and suggested before ${ }^{23-24}$. We have chosen streptomycin-treated mice containing reduced normal ûora for our research because these animals have proven to be amenable to EHEC colonization.

The major virulence factor and a defining characteristic of $E$. coli O157:H7 is the production of Shiga toxin. This potent cytotoxin is the factor that leads to death and many other symptoms in patients infected with EHEC ${ }^{13}$. Our work involves the exploitation of $s t x 1 A$ and $s t x 2 A$ positive $E$. coli $\mathrm{O} 157$ in healthy streptomycintreated Swiss albino mice to investigate the clinical manifestation exerted by this clinical strain.

Various doses of E. coli O157 in (Table 1) were applied through three alternative routes (oral, intramuscular and intraperitoneal) into the rodents. The mice were housed and maintained under E. coli $\mathrm{O} 157$ free condition and were followed for six subsequent days after deliberate microbial infection.

The highest titer of orally added E. coli 0157:H7 $\left(10^{9} \mathrm{CFU} \mathrm{ml}{ }^{-1}\right)$ among the five test doses started to show symptoms earlier than other doses and manifested all the classical symptoms i.e. decreased physical activity, ruffled fur, general lethargy, hunchback posture, exudative accumulation around partially closed eyes, bloody stool, fever, being moribund and finally death. Death was attributed to septic shock due to toxins present in the circulation of mice after challenge with the bacteria. All mouse models receiving the control treatment (PBS only) did not show any sign of bacteremia or illness. This in vivo assessment suggests that E.coli O157:H7 evoked a range of illness in rodent model, which partially resemble the symptoms exerted by $\mathrm{O} 157$ infection in humans. For the orally inoculated mice population with highest dose, symptoms started to manifest at $14^{\text {th }} \mathrm{hr}$, increased with time and the mice reached moribund condition near at $48^{\text {th }} \mathrm{hr}$ (Table 3 ) just before being dead. It is worthwhile to mention that these clinical features expressed by the murine model in this study coincide with the finding by other researchers ${ }^{21}$. However, it is suggested that there is no animal model system that mimics the full spectrum of 0157-evoked illness in humans specially the development of $\mathrm{HC}$ and $\mathrm{HUS}^{17}$.

Oral route provoked disease severity earlier and of greater degree than other routes. The orally infected mice died near $48^{\text {th }}$ hour whereas mice inoculated by i.m. or i.p. developed experimentally induced gastroenteritis near $48^{\text {th }}$ hr but recovered partially by 72 hrs and hence escaped death. Therefore, it can be speculated that for i.m. and i.p. routes, MLD in mice would be greater than $1 \times 10^{9} \mathrm{CFU} \mathrm{ml}{ }^{-1}$ for $E$. coli O157:H7. Considering all these results, the oral route of $E$.coli O157:H7 addition at the dose of $100 \mu \mathrm{l}$ suspension containing $1 \times 10^{9} \mathrm{CFU} \mathrm{ml}{ }^{-1}$ was taken as the most potent concentration in producing $\mathrm{O} 157$ fatality and hence selected as the MLD. The present investigation well agrees with the previous findings where it was concluded that the test rodents inoculated by nonhaemorrhagic $E$. coli through intraperitoneal route at different concentrations $\left(1 \times 10^{5} \mathrm{CFU} \mathrm{ml}^{-1}, 1 \times 10^{7} \mathrm{CFU} \mathrm{m}{ }^{-1}\right.$, $1 \times 10^{9} \mathrm{CFU} \mathrm{ml}{ }^{-1}$ ) gave the MLD value of $10^{7} \mathrm{CFU} / \mathrm{ml}$ as it induced fatality in all replicates within 24 hrs ${ }^{21}$. The experiment was not prolonged after 6 days to avoid the likelihood of contamination with other prevailing microorganisms, which would have interfered with the clinical picture. To verify if the cause of death was truly due to $E$. coli bacteremia, blood samples were collected from dead mice by cardiac puncture and were streaked on CT-SMAC agar to compare the bacteria recovered from the blood to the original inoculum, clinical isolate of $\mathrm{E}$. coli O157:H7.

By comparing the pattern of body weight change with the degree of disease severity in this work, it could be concluded that weight decrease in infected rodents is proportional to the increase rate of symptom acquisition and severity. This observation was common for all the three routes of bacterial inoculation investigated in this research. The untreated mice group developed none of the aforementioned symptoms (Table 2) and acquired adequate body weight within the studied time frame.

As a result of the increased rate of HC and HUS over the last several years and the lack of therapies for treatment of HUS, further research is necessary to deûne mechanisms involved in the pathogenesis of E. coli O157:H7 and to identify potential disease prevention strategies and therapeutics. The application of animal model systems is vital to achieve these goals. Despite the fact that no one animal model recapitulates all features of E.coli O157:H7 infection, mouse models have been explored in this research for understanding E. coli O157:H7 pathogenesis better. The findings from this study can help to pinpoint the means by which $E$. coli O157:H7 infection and/or disease can be controlled or prevented.

\section{References}

1. Riley L. W., Remis R. S., Helgerson S. D., H. B., McGee J. G., Wells B. R.,Davis R. J., Hebert E. S., Olcott L. M., Johnson N. T., Hargrett P. A.and Cohen M. L. 1983. Hemorrhagic colitis associated with a rare Escherichia coli serotype. N. Engl. J. Med. 308:681-685.

2. Akashi S., Joh K., Tsuji A. 1990. A severe outbreak of haemorrhagic colitis and haemolytic uraemic syndrome associated with Escherichia coli 0157:H7 in Japan. Eur. J. Pediatr.650-655.

3. Griffin P.M. and Tauxe R.V. 1991.The epidemiology of infections caused by Escherichia coli O157:H7, other enterohemorrhagic E. coli, and the associated hemolytic uremic syndrome. Epidemiol. Rev. 13: 60-98.

4. Brandit M. L., O’Regan S , Rousseau E., and Yazbeck S. 1990. Surgical complications of the hemolytic-uremic syndrome. J. of Pediatr. Surg, vol. 25, no. 11, pp. 1109-1112.

5. Robert L. B., Michael P. D.1997. Food borne disease significance of E.coli O157:H7 and other enterohemorrhagic E.coli. Scientific status summary.

6. Cody S. H., Glynn M. K. and Glynn M. K.1999. An outbreak of Escherichia coli O157:H7 infection from unpasteurized commercial apple juice. Ann.of Intern.Med., 130(3): pp. 202-209. 
7. Bell B. P., Goldoft M., Griffin P. M., Davis M. A., Gordon D.C., Tarr C.A., Bartleson J., Lewis H., Barrett T. J., Wells J. G. 1994. A multistate outbreak of Escherichia coli O157:H7-associated bloody diarrhea and hemolytic uremic syndrome from hamburgers. The Washington experience JAMA 272:1349-1353.

8. Cagney C. H., Crowley G., Duffy J. J., Sheridan S., O’Brien E., Carney W. A., Anderson D. A., McDowell and Blair I. S. 2004. Prevalence and numbers of Escherichia coli O157:H7 in minced beef and beef burgers from butcher shops and supermarkets in the Republic of Ireland. Food Microbiol. 21:203-212.

9. Mead P.M., Slutsker L., Dietz V., McCaig L.F., Bresee J.S., Shapiro C., Griffin P.M. and Tauxe R.V. 1999. Food-related Illness and Death in the United States. Emerg. Infect. Dis. 5:607-625.

10. Doyle M. P. and Meng J. 1998. Microbiology of Shiga toxin-producing Escherichia coli in foods and other Shiga Toxin-Producing E. coli Strains. J. B. Kaper and A. D. O’Brien, Eds., pp. 92-108, ASM Press, Washington, DC, USA.

11. McKee M.L. and O’Brien A.D.1996.Truncated enterohemorrhagic Escherichia coli (EHEC) O157:H7 intimin (EaeA) fusion proteins promote adherence of EHEC strains to HEp-2 cells. Infect. Immun., 64(6), 2225-2233.

12. Kaper J.B., Elliott S., Sperandio V., Perna N.T., Mayhew G.F. and Blattner F.R. 1998. Attaching and effacing intestinal histopathology and the locus of enterocyte effacement. In Escherichia coli and other Shiga toxin-producing E. coli strains. Kaper JB, O’Brien AD eds. Washington DC, ASM Press, pp 163-82.

13. Nataro, J. P., and J. B. Kaper. 1998. Diarrheagenic Escherichia coli. Clin. Microbiol. Rev. 11: 142-201.

14. Bru“ssow H., Canchaya C., Hardt W.D. 2004. Phages and the evolution of bacterial pathogens: from genomic rearrangements to lysogenic conversion. Microbiol. Mol. Biol. Rev. 68: 560-602.

15. March Sandra B. and Ratnam S. 1986. Sorbitol-MacConkey medium for detection of Escherichia coli 0157:H7 associated with hemorrhagic Colitis. p. 869-872.
16. Sheng H., Knecht H. J., Kudva I. T. and Hovde C. J. 2006. Application of bacteriophages to control intestinal Escherichia coli O157:H7 levels in ruminants. Applied and Environmental Microbiology, 72(8): 5359-5366.

17. Krystle L.M. and Alison D. O’Brien. 2011. Mouse models of Escherichia coli O157:H7 infection and shiga toxin injection. J. of Biomedic. and Biotec. Article ID 258185.

18. Khan A., Simanti D., Das S.C. , Ramamurthy T., Khanam J., Takeda Y., Bhattacharya S.K. and Nair G.B. 2003. Shiga toxin producing Escherichia coli infection: current progress \& future challenges. Ind. J. Med. Res. 118: 1-24.

19. Nelson J.E. and Knawetz S.A. 1992. Purification of cloned and genomic DNA by Guanidine thiocyanate/isobutyl alcohol fractionation. Anal. Biochem. 207: 197-201.

20. Brown T.A. 2006. Gene Cloning and DNA Analysis: An Introduction. $5^{\text {th }}$ Ed.

21. Lemuel B. R. N., Remedios S., Flamiano M.S.2004. Use of bacteriophages as therapy for Escherichia coli-induced bacteremia in mouse models.Phil.J .Microbiol. Infect. Dis. 33(2):47-51.

22. Sawamura S., Tanaka K., and Koga Y.1999. Therapeutic effects of antibiotics against enterohemorrhagic Escherichia coli (EHEC) O157:H7 (O157) infection: in vivo analysis using germfree mice. The Journal of the Japanese Association for Infectious Diseases, 73(10): 1054-1063.

23. Isogai E., Isogai H., and Isogai H. 2000. Effect of antibiotics, levofloxacin and fosfomycin on a mouse model with Escherichia coli 0157 infection. Microbiology and Immunology, 44(2): 89-95.

24. Isogai E., Isogai H., Kimura K., Hayashi S., Kubota T., Fujii N., and Takeshi K. 1998. Role of tumor necrosis factor alpha in gnotobiotic mice infected with an Escherichia coli 0157:H7 Strain. Infect. Immun., 66(1): 197-202.

25. Zinnah M. A., Haque M. H., Islam M. T., Hossain M. T., Bari M. R., Babu S. A. M., Rahman M. T. and Islam M. A. 2008. Drug sensitivity pattern of $E$. coli isolated from samples of different biological and environmental sources. Bangl. J. Vet. Med 6 (1): 13-18. 